\section{Mateusz Antoniuk}

Uniwersytet Jagielloński

\title{
Jak czytać stronę brulionu. Krytyka genetyczna i materialność tekstu
}

\section{Abstract \\ How to Read a Page of a Draft: Genetic Criticism and Material Textuality}

The starting point of the study is the question whether the notions of the "bibliographic code" and "linguistic code" (introduced in George Bornstein's article How to Read a Page. Modernism and Material Textuality) can be applied in the field of genetic criticism. Next, the author focuses on the genesis of Aleksander Wat's poem U szczytu antynomij [At the Peak of Antinomies], whose subsequent drafts evolved in terms of not only their linguistic but also bibliographic code. In conclusion, some remarks are presented concerning the auracity of the manuscript, a possible new edition of Wat's poem and the methodological alliance between genetic criticism and studies into the materiality of the text.

Słowa kluczowe: krytyka genetyczna, materialność tekstu, kod bibliologiczny, kod lingwistyczny, poezja Aleksandra Wata

Keywords: genetic criticism, material textuality, bibliographic code, linguistic code, Aleksander Wat's poetry 
Tytuł mojego szkicu jest parafrazą. Nawiązuję w nim do tytułu, jaki nosi artykuł otwierający „kartkowy” numer „Wielogłosu” i będący tłumaczeniem pierwszego rozdziału książki Material Modernism. The Politics of the Page autorstwa George'a Bornsteina. Ów stylistyczny zabieg eksponować ma zależność mojego wystąpienia od dyskursu amerykańskiego literaturoznawcy. To, co zamierzam powiedzieć odnośnie do tego, co stwierdził Bornstein, określić wypada mianem adaptacji czy transpozycji. Najkrócej rzecz ujmując, podejmę próbę przeniesienia konceptów testowanych przez autora Materialnego modernizmu na grunt, dla którego nie były one przeznaczone, a mianowicie w dziedzinę krytyki genetycznej.

George Bornstein nie jest krytykiem genetycznym, nie zalicza się do kręgu amerykańskich badaczy procesu tekstotwórczego ${ }^{1}$. Jego studium dotyczy materialnych form istnienia dwudziestowiecznej (po części dziewiętnastowiecznej) literatury amerykańskiej i zachodnioeuropejskiej, ale - to ważne zastrzeżenie - literatury publikowanej, funkcjonującej w obiegach czytelniczych. „Stroną” czy „kartką”, której „polityka” interesuje Bornsteina, jest przede wszystkim strona drukowanej książki. Manuskrypty w polu uwagi badacza pojawiają się stosunkowo rzadko, a jeśli już tak się staje - są to autografy nie brulionowe (którymi karmi się krytyka genetyczna), lecz czystopisowe, wykonywane jako specyficzna forma rozpowszechniania literatury nowoczesnej (a więc dla krytyki genetycznej właściwie bezużyteczne). Takie właśnie, jak autograf sonetu Emmy Lazarus, sporządzony z myślą o wystawieniu na aukcji, będącej wydarzeniem społecznym i politycznym, a więc dokument mało mówiący o historii wytwarzania tekstu, wiele natomiast o socjologiczno-kulturowym modusie jego funkcjonowania. Procesem tekstotwórczym - dodajmy - niespecjalnie interesują się także ci badacze anglosascy, na których Bornstein powołuje się w swojej pracy, od których zapożycza terminologię (Donald Francis McKenzie, Peter Shilinsburg, Jerome McGann).

Pierre-Marc de Biasi, klasyk krytyki genetycznej, powiada, iż najpóźniejsza kontrolowana przez autora edycja tekstu (ewentualnie: edycja post mortem, będąca ekspresją ostatniej autorskiej intencji) „wyznacza końcową granicę pola badań należących do genetyki autorskiej”. I zastrzega, że czyni to „,bez uszczerbku dla badań składających się na genetykę post-autorską, która będzie się zajmować przekształceniami dzieła po śmierci jego autora, to zna-

${ }^{1}$ W literaturoznawstwie amerykańskim zarysowuje się linia badań nad tą tematyką, począwszy od „założycielskiej” książki Poets at Work z połowy ubiegłego stulecia (R. Arnheim et al., Poets at Work: Essays based on the modern poetry collection at the Lockwood Memorial Library, introduction by Ch. Abbott, New York 1948), przez prace z lat sześćdziesiątych i siedemdziesiątych, powstające jeszcze w kręgu inspiracji nowokrytycznej (A.W. Litz, The Art of James Joyce: Method and Design in „Ulysses” and „Finnegans Wake”, London 1961; C. Bradford, Yeats at Work, Carbondale-Edwardsville 1965; M. Groden, „Ulysses” in Progress, Princeton 1977), aż do najnowszych publikacji, powstałych po roku 2000 (m.in. antologia amerykańskich przekładów z francuskiej krytyki genetycznej czy publikowane w USA książki badaczy europejskich, takich jak D. van Hulle, H. Sullivan, S. Bushell). 
czy dalszym istnieniem tekstu" ${ }^{2}$. W kategoriach Biasiego, studium Georga Bornsteina mogłoby zostać określone tak właśnie: jako znakomity przykład „genetyki postautorskiej”. W niewielkim uproszczeniu wolno powiedzieć, iż domena badawcza książki o materialnym modernizmie zaczyna się tam, gdzie kończy się terytorium critique génétique.

A jednak terminologia Bornsteina pozwala się udatnie zastosować do opisu nie tylko publikacyjnej egzystencji dzieła, lecz także jego brulionowej preegzystencji. Przede wszystkim zaś: dla krytyka genetycznego atrakcyjny może być kryjący się w tej terminologii sposób rozumienia tekstu, jego ontologii, dynamiki przemian, jego historii. Zapewne, nie zawsze, nie w każdym przypadku, z jakim styka się badacz brulionu, kategorie stosowane przez badacza „materialnego modernizmu” okażą się równie operatywne. Czasem jednak warto je potraktować jako narzędzie czy choćby - inspirację.

Próba terminologicznego i myślowego powiązania amerykańskich studiów nad materialnością literatury z francuską krytyką genetyczną została już przeprowadzona. W roku 2013 na łamach tekstologicznego czasopisma „Variants”, będącego oficjalnym organem ESTS ${ }^{3}$, ukazał się artykuł fińskiego tekstologa Veijo Pulkkinena, opatrzony znamiennym tytułem: A Genetic and Semiotic Approach to the Bibliographical Code Exemplified by the Typography of Aaro Hellaakoski's „Dolce far Niente”. Autor podejmuje w nim, stosowany i rozwijany przez Bornsteina, Shillingsburga i McGanna, koncept „kodu bibliologicznego”. Podejmuje - na sposób genetyczny. Pulkkinena interesuje nie tyle ustalony, skonfigurowany już kod bibliologiczny gotowego dzieła, ile raczej sam proces jego planowania i konfigurowania. Badacz postuluje uprawianie „genetyki bibliologicznej” - jej przedmiotem miałby być proces tekstotwórczy polegający nie tylko na wypracowywaniu przez pisarza leksykalno-frazeologicznej, retorycznej struktury tekstu, lecz również na autorskim projektowaniu materialnej postaci, w jakiej tekst ma się ukazać światu. Przykładem, na którym Pulkkinen testuje swoją koncepcję, jest genetyczne dossier Dolce far Niente, ,poematu wizualnego" opartego na eksperymentalnej typografii i opublikowanego w roku 1928 przez fińskiego poetę Aaro Hellaakoskiego (1893-1952). Zachowane dokumenty genezy takie jak manuskrypt, maszynopis z ręcznymi adnotacjami, szczotki wydawnicze - były miejscem (obecnie zaś są śladem) równoległego wytwarzania i przetwarzania leksyki oraz grafiki poematu. Hellaakoski testował rozmaite rozwiązania: zmieniał położenie wyrazów na kartce, wyróżniał niektóre słowa za pomocą wersalików. Nanosił też liczne uwagi przeznaczone dla ,składacza", dotyczące doboru czcionki czy przestrzennego rozplanowania tekstu na stronie. Jak stwierdza Pulkkinen, w roboczych, warsztatowych zapisach

${ }^{2}$ P.-M. de Biasi, Genetyka tekstów, przeł. F. Kwiatek, M. Prussak, Warszawa 2015, s. 85.

${ }^{3}$ European Society for Textual Scholarship - organizacja zajmująca się rozwojem badań tekstologicznych, zwłaszcza wymianą doświadczeń między europejskimi tekstologami i edytorami. 
fińskiego modernisty zawarty jest dynamiczny, stopniowo przekształcający się projekt kodu bibliologicznego, ostatecznie zrealizowanego (choć nie w pełni i nie bez odstępstw od planu) w pierwodrukowej edycji ,„poematu wizualnego"4.

„Genetyka bibliologiczna" Veijo Pulkkinena sytuuje się więc istotnie na pograniczu dwu praktyk badawczych: francuskiej krytyki genetycznej i amerykańskiej bibliologii. Można powiedzieć: za pomocą narzędzi praktyki pierwszej pokazuje, jak powstaje przedmiot badań drugiej. Albo, inaczej mówiąc: terminologię preferowaną przez drugą praktykę badawczą włącza w aparat pojęciowy pierwszej praktyki badawczej. Przywołuję ów integrujący koncept - w koniecznym skrócie, a więc i w nieuchronnym uproszczeniu ${ }^{5}$ - gdyż znajduję w nim zachętę oraz inspirację do poszukiwania możliwych punktów stycznych między optyką amerykańskich studiów nad materialnością literatury i optyką francuskich studiów nad brulionowym śladem procesów tekstotwórczych. Moja własna propozycja „genetycznej operacjonalizacji” kategorii wywiedzionych z prac takich, jak praca Bornsteina, ma charakter podobny - choć nie identyczny.

Przedmiotem obserwacji chcę uczynić proces wytwarzania jednego wiersza Aleksandra Wata. Wiersz ów - pisany i przepisywany, podlegający kolejnym, brulionowym opracowaniom, wreszcie zaś oddany „księgodajcom by zdruczyli" - stopniowo się zmieniał. Z każdą następną odsłoną inaczej brzmiał i inaczej wyglądał, podobnie jak inaczej brzmiał i wyglądał w każdej ze swych prepublikacyjnych symulacji wizualny poemat Dolce far Niente. Wydaje mi się jednak, że historię materialnych przemian tekstu polskiego opowiedzieć trzeba inaczej niż Pulkkinen opowiada historię materialnych przemian tekstu fińskiego. Dla Pulkkinena manuskrypt, maszynopis czy wydawnicza makieta Dolce far Niente były - najkrócej mówiąc - etapami w procesie stopniowego wykształcania kodu bibliologicznego zastosowanego w pierwszej edycji. Dla mnie natomiast manuskrypty i maszynopisy Wata będą raczej etapami w procesie zacierania, zanikania pierwotnych, materialno-wizualnych właściwości tekstu: historia, którą opowiem, będzie zatem historią nie tyle progresu, ile utraty.

Zmieniające się brzmienie tekstu (jego leksykę, frazeologię) określał będę mianem kodu lingwistycznego, zmieniające się parametry materialności tekstu - także wpływające, co spróbuję pokazać, na jego znaczenie - nazywał będę mianem kodu materialnego. Bornstein stosuje to pojęcie tylko raz, jak można rozumieć, na prawach synonimicznego zamiennika wobec pojęcia kodu bibliologicznego - ja natomiast wolę posługiwać się właśnie taką formu-

${ }^{4}$ V. Pulkkinen, A Genetic and Semiotic Approach to the Bibliographical Code Exemplified by the Typography of Aaro Hellaakoski 's ,Dolce far Niente”, „Variants” 2013, nr 10, s. $163-186$.

${ }^{5}$ Pomijam w moim omówieniu artykułu z „Variants” kwestię dla Pulkkinena istotną, właściwie pierwszorzędną: próbę powiązania kategorii „kodu bibliologicznego” z Peirce'owską semiotyką. 
łą: kod materialny. Przymiotnik „bibliologiczny” samą swą etymologią odsyła do pojęcia „książki”, a przecież mnie interesować tu będą przede wszystkim prepublikacyjne inkarnacje tekstu in statu nascendi ${ }^{6}$.

\section{Historia wiersza - cztery odsłony}

Dokumentacja procesu tekstotwórczego, który stanie się przedmiotem analizy, znajduje się (wraz z całym archiwum Wata) w zbiorach Beinecke Rare Book \& Manuscript Library, Yale University ${ }^{7}$. Składają się na nią (według mojej wiedzy - archiwum jest rozległe i niezbyt dokładnie zinwentaryzowane, nie sposób wykluczyć, iż jakieś dokumenty „przegapiłem”) dwa brulionowe rękopisy oraz jeden maszynopis. W języku krytyki genetycznej ów zbiór dokumentów określić można mianem dossier dzieła. Praca krytyka genetycznego polega na sformułowaniu hipotezy, określającej chronologiczną kolejność oraz funkcjonalną zależność poszczególnych dokumentów (a więc: która wersja jest późniejsza, która wcześniejsza, ale też: jakie relacje wynikowe, przyczynowo-skutkowe zachodzą między poszczególnymi wersjami). Inaczej mówiąc, krytyka genetyczna stawia sobie za cel stworzenie narracyjnej reprezentacji dossier - reprezentacji, która jest jego (słabszą lub silniejszą) interpretacją̧. To właśnie spróbuję teraz uczynić: trzy zachowane i odnalezione przeze mnie dokumenty procesu tekstotwórczego (a więc dossier bardzo niewielkie) zostaną ułożone w zrekonstruowanym porządku chronologicznym i funkcjonalno-relacyjnym.

${ }^{6}$ Prezentowane $\mathrm{w}$ tym artykule stanowisko miałem okazję przedstawić $\mathrm{w}$ formie referatu i poddawać pod dyskusję na forum krajowym (na macierzystym Wydziale Polonistyki UJ podczas zebrania naukowego Katedry Historii Literatury Polskiej XX Wieku oraz w Ośrodku Badań nad Literaturą Religijną KUL) i międzynarodowym (referaty na konferencjach: „Digital Scholarly Editing: Theory, Practice, Methods”, European Society for Textual Scholarship, Antwerpia, 5-7.10.2016; „Traumatic Modernities. From Comparative Literature to Medical Humanities”, Uniwersytet Jagielloński, 19.04.-21.04.2017; „Textual Embodiments", Society for Textual Schollarship, University of Maryland, College Park, 31.05.-2.06.2017).

${ }^{7} \mathrm{Z}$ dokumentacją tą mogłem się zapoznać dzięki kwerendzie wykonanej w ramach programu grantowego Uniwersytetu Yale pod nazwą ,Fellowships for Visiting Postdoctoral Scholars" (2014).

${ }^{8}$ Jak wiadomo, tę dyskursywną reprezentację i interpretację dossier francuska krytyka genetyczna określiła mianem przedtekstu (oryg. avant-texte). W moim szkicu unikam pojęcia przedtekstu nieprzypadkowo - wikła nas ono w problem tekstowego lub nietekstowego statusu brulionu, co z kolei odsyła do zagadnień z zakresu definicji i ontologii tekstu jako takiego. Sprawy to z pewnością istotne, tym razem staram się je wszakże ominąć. Nie w pełni konsekwentnie: pisząc w dalszej części artykułu o brulionowych wersjach czy wcieleniach tekstu, opowiadam się za stanowiskiem, w myśl którego utwór zapisany w brulionie jest już tekstem właśnie, nie zaś czymś, czemu kwalifikacja „tekstowości” nie w pełni przysługuje. 
a) Odsłona pierwsza

Pod koniec życia, około roku 1967, Aleksander Wat sporządził pierwszy szkic nowego wiersza ${ }^{9}$. Oto transliteracja tego dokumentu ${ }^{10}$ :

\author{
$\mathrm{U}$ \\ szczytu \\ wszystkich antynomij: \\ owo co z czasu jest \\ contra \\ i owo co z przestrzeni.
}

Zuchwały, „ogłosiłem się carem przestrzeni,

wrogiem wnętrza i czasu"

To była młodość

zielona.

W wieku klęski, głupi,

liznąwszy teorii względności,

łudziłem się poezją wpisać ją w formułę ezasoprzestrzeni.

czasoprzestrzeni

Teraz, gdy czas pokonał mnie, połamał,

ta

Przestrzeń, ona wspaniałomyślna,

ofiaruje 0,3 łokci sześciennych

na dożywocie

dla moiehm kościom.

$\mathrm{Z}$ braku rejenta umowę spisujemy w szynku

Gdzie szynkarka i kowal postawili krzyżyki

ja popisuję się jeszcze [...] kaligrafią:

energiczną kreską przytwierdzam t do [...]

który [...] sam zdarłem z mego [?] czoła

spłachetka skóry

${ }^{9}$ Dopowiedzenie chronologiczne: żaden z zachowanych i omawianych tu i dalej dokumentów genezy nie jest bezpośrednio datowany przez autora. Szacunkowe określenie czasu powstawania utworu przyjmuję za Adamem Dziadkiem, pierwszym - o czym przyjdzie jeszcze powiedzieć - edytorem wiersza. Komentując interesujący mnie liryk oraz dwa inne, także niedatowane wiersze o incipitach Po promieniu księżyca... i Ból zamknięty $w$ stoju $z$ Leyty..., Dziadek powiada: „Ustalenie daty ich powstania jest trudne. Zważywszy jednak na tematykę, wnioskować trzeba, że powstały pod koniec życia autora Ciemnego świecidta” (A. Dziadek, Aleksander Wat w Beinecke Library w Yale, „Teksty Drugie” 2009, nr 6, s. 253).

${ }^{10}$ Lokalizacja dokumentu: Beinecke Rare Book \& Manuscript Library, Yale University, Aleksander Wat Papers, GEN MSS 705, Series II Writings, Box 22, Folder 465. Panu Andrzejowi Watowi, synowi Aleksandra Wata, najserdeczniej dziękuję za uprzejmą zgodę na cytowanie i reprodukowanie brulionów Poety. 
obeszło się bez Apoljona Marsjaszu,

bo i niezdatne ono na nic

i boli mnie bardzo ${ }^{11}$

Jak łatwo zauważyć, Wat nie pozostawił w pierwszym autografie licznych śladów wahań, rozterek, gwałtownych zmian koncepcji. Nie wiemy oczywiście - brulion nam tego nie ujawni - jak przebiegał ewentualny namysł nad tekstem w fazie preinskrypcyjnej (to jest zanim autor pochylił się nad kartką). Jasne jest natomiast, że już pierwsze zetknięcie piszącego narzędzia i nośnika inskrypcji owocuje powstaniem spójnego utworu poetyckiego o klarownie zarysowanej sytuacji lirycznej. Owszem, tekst w ten sposób zaistniały podlega rewizji. Jednak skreślenia i substytucje nanoszone na pierwszy zapis są nieliczne, żadna z wykonanych operacji „teksto-przetwórczych” nie pociąga za sobą radykalnej inwersji semantycznej. $Z$ pewnością nie da się patrzeć na ten brulion, jak na protokół trudnych, długo odraczanych wyborów, rozstrzygnięć, których stawką będzie modyfikacja globalnego sensu utworu.

Sens ów, jak myślę, można sparafrazować następująco: wiersz Aleksandra Wata rodzi się jako, po pierwsze, forma autoironicznego rozliczenia poety z iluzjami młodości, po drugie, próba zrozumienia nieuleczalnej choroby bólowej, po trzecie wreszcie - jako spojrzenie w stronę bliskiej już śmierci. Poeta na zasadzie dokładnego, formalnego autocytatu przywołuje juwenilny poemat prozą JA z jednej strony $i$ JA z drugiej strony mego mopsożelaznego piecyka, gdzie istotnie zawarty jest passus: „Ogłosiłem się carem przestrzeni, wrogiem wnętrza i czasu. Posiadłszy radosną wiedzę maski, pałałem cudowną żądzą: uprzestrzenić się!" 12 . Fraza z roku 1919, powtórzona w wierszu z około roku 1967, okazuje się jednak zapowiedzią niespełnioną: świat pozostał niezdobyty, zdobywca in spe poznał swoją dojmującą ograniczonośćc ${ }^{13}$. Próba samounieśmiertelnienia

$11 \mathrm{~W}$ transliteracji przyjęto następujący system oznaczeń: [...] - wyraz nieodczytany, [?] - lekcja niepewna (znak odnosi się do wyrazu, po którym następuje), wyrazy przekreślone przez poetę oddano czcionką przekreśloną. Zgodnie z zasadami transliteracji (w zachodniej krytyce genetycznej określanej mianem „,transkrypcji dyplomatycznej”) podjęto próbę maksymalnie wiernego odwzorowania topografii zapisu i kartki (położenia wyrazów względem siebie i względem marginesów). Zapis, dodajmy, został jeszcze poprzecznie przekreślony za pomocą dwu ukośnych kresek. Fakt, iż autor pracował dalej nad tekstem pozwala stwierdzić, że przekreślenie miało charakter gestu technicznego, rzec można, mnemotechnicznego. W ten sposób poeta „oznaczał” manuskrypt, kiedy tekst w nim zawarty został już przepisany na kolejną kartkę w celu dalszego opracowywania.

12 A. Wat, Wybór wierszy, oprac. A. Dziadek, Wrocław 2008, s. 8-9.

13 Użyta w tym wierszu strategia operowania autocytatem z Piecyka ... przypomina tryb autocytacji, zastosowany już przez Wata we wcześniejszym o lat przeszło dziesięć wierszu Noc $w$ szpitalu, datowanym na rok 1956. Przypomnijmy: poeta rozpoczyna utwór od wiernego powtórzenia frazy z Piecyka: „«Słowiki już śpiewają mi na śmierć. A także pawie»”. Ów wywołany z przeszłości passus zostaje następnie opatrzony charakterystycznym komentarzem: „Tak pisałem, gdy miałem lat dwadzieścia. / Teraz po trzydziestu pięciu jakże trudnych latach / słowiki naprawdę śpiewają mi na śmierć / w ogrodzie w Saint-Mandé, śród starych akacyj" (zob. A. Wat, op.cit., s. 76-77). W tym wypadku powtórzenie 
poprzez sztukę zawodzi, więcej - ściąga karę na niefortunnego hegemona czasu i przestrzeni. Porównując się do odzieranego ze skóry Marsjasza, Wat poddaje zarazem sugestię odnośnie do przyczyny swego cierpienia ${ }^{14}$. Tortury, jakim podlega Marsjasz, są karą za zuchwałość, wyrażającą się w podjęciu artystycznej rywalizacji z bogiem artystów; tortury, których doświadcza Wat, są konsekwencją hybris, wyrażającej się w pragnieniu przekroczenia ludzkich ograniczeńn ${ }^{15}$. Ostatecznie niegdysiejszy i samozwańczy „car przestrzeni” zdany jest na jej łaskę, będącą szyderczą zemstą bardziej niż aktem wspaniałomyślności. Przestrzeń mianowicie ofiarowuje poecie dar nie do odrzucenia - grób.

Frapuje mnie sprawa tego wiersza. Prócz wszystkiego, o czym była dotąd mowa (i co już samo w sobie mogłoby się stać przedmiotem obszernej interpretacji), odnajduję w tym tekście coś jeszcze, coś więcej, coś co wiąże się ściśle z powyższymi rozpoznaniami, zarazem jednak poza nie wykracza. Moja uwaga skupia się na fantazmacie makabrycznego dermo-manuskryptu. Cóż to za rękopis? Oczywiście - rękopis umowy zawartej między donatorem (przestrzenią) a obdarowanym (Aleksandrem Watem), posiadającej kontrasygnatę świadków (szynkarki i kowala), a dotyczącej aktu darowizny grobu. Ale ta „umowa”, zważmy, jest zarazem czymś bardziej elementarnym - tekstem po prostu. Jeśli zaś umowa jest tekstem zapisanym na żywcem zdartej z czoła skórze, to cały wiersz może zostać zrozumiany jako paraboliczna figura związku bólu i pisma, cierpienia i pisania.

Podobną metaforę Wat wytworzył już w liryku wcześniejszym, pochodzącym z lat pięćdziesiątych, opublikowanym w tomie Wiersze z roku 1957.

Trochę mitologii

Ja nie jestem Heraklesem

ani Ola Dejanirą,

wrogi moje nie centaury.

frazy z młodzieńczego poematu prozą nie wiązało się więc z zaprzeczeniem jej sensu, lecz z jej - nieoczekiwanym - potwierdzeniem przez rzeczywistość. Potwierdzeniem mającym jednak wydźwięk zarazem tragiczny i ironiczny.

${ }^{14}$ O Marsjaszu jako figurze losu Aleksandra Wata pisał przed laty Jan Zieliński; wiersz *** U szczytu antynomij nie był wówczas znany, badacz „marsjaszową" metaforę wyprowadzał z pewnych fragmentów Dziennika bez samogłosek oraz sławnego wiersza Zbigniewa Herberta (zob. J. Zieliński, Dwudziestowieczny Marsjasz, posłowie do: A. Wat, Poezje, Warszawa 1997, s. 481-482). Notabene, wiersz Herberta był już opublikowany pod koniec lat sześćdziesiątych, Wat poezją autora Studium przedmiotu żywo się interesował i wysoko ją cenił, być może więc utwór *** U szczytu antynomij jest także rodzajem ukrytej korespondencji poetyckiej z młodym (dla Wata wówczas wciąż jeszcze młodym) poetą krajowym.

${ }_{15}$ Tym samym liryk *** U szczytu antynomij pozwala się wpisać w serię tych utworów i wypowiedzi, w których Wat testuje rozmaite warianty jednej, w gruncie rzeczy, i tej samej myśli: moja choroba bólowa to cena płacona przeze mnie za to, co - niegdyś - czyniłem lub próbowałem czynić. Por. wiersze Buchalteria (wraz z przenikliwą interpretacją Mariana Stali w jego książce Blisko wiersza: 30 interpretacji, Kraków 2013, s. 73-80), Hybris, fragmenty Dziennika bez samogłosek etc. 


\author{
Lecz koszuli ja Nessosa \\ już się nie pozbędę nigdy. \\ Ona wlewa w żyły ołów, \\ ona trawi w wolnym ogniu \\ limf rysunek, nerwów deseń. \\ Ona tkankę miażdży żywą, \\ kość rozkrusza, mózg zaciska. \\ Żeby wyżąc $\mathrm{z}$ krwawym potem \\ słowa słowa słowa ${ }^{16}$.
}

Choroba bólowa jest tutaj, w tej symbolicznej projekcji, czynnikiem zarazem destruktywnym i (słowo)twórczym: z bólu, z bolącej „somy”, rodzi się „logos”. Mówiąc jeszcze inaczej: choroba unicestwia ciało i wytwarza pojawiające się niejako „zamiast” ciała, „w miejsce” ciała - słowa. W wierszu *** U szczytu antynomij - tak jak go czytam i rozumiem - dzieje się coś porównywalnego. Ciało musi zostać boleśnie uszkodzone, poddane fragmentaryzacji, aby przemówił tekst. „Im dłużej czytam wiersze Wata - powiada Krystyna Pietrych - tym częściej mam poczucie obcowania z dziełem wyjątkowym, które powstało w równej mierze z bólu, jak i pomimo bólu" ${ }^{17}$. Czyli, jak rozumiem, doświadczenie traumatyczne znajduje w poezji Wata swą (z pewnością ułomną) ekspresję (w tym sensie Watowe wiersze są „z bólu”), a równocześnie to samo doświadczenie traumatyczne ,utrudnia” (eufemistycznie rzecz ujmując) wszelką aktywność, a więc i tworzenie poezji (w tym sensie Watowe wiersze są ,pomimo bólu”). Liryk *** U szczytu antynomij byłby - w proponowanej przeze mnie optyce lekturowej - wierszem metaforyzującym ów ambiwalentny związek traumy i pisma. Aby sporządzić inskrypcję, poeta musi przezwyciężyć ból (to znaczy uprawiać kaligrafię, mając dopiero co oskalpowaną głowę), ale też musi doznać bólu, by akt zapisu stał się w ogóle możliwy (zerwana z czoła skóra jest najwyraźniej jedyną dostępną dla poety kartką, jedynym możliwym nośnikiem inskrypcji).

Docieramy tym samym do konkluzji: wiersz *** U szczytu antynomij jest nie tylko wierszem somatycznym, lecz także autotematycznym. Ściślej, lepiej rzecz ujmując: jest równocześnie wierszem somatycznym i wierszem autotematycznym, jest somatycznym metawierszem. Fantazmat makabrycznego dermo-manuskryptu okazuje się - fantazmatem tekstotwórczości bólu ${ }^{18}$.

16 A. Wat, op.cit., s. 76.

${ }_{17}$ K. Pietrych, Co poezji po bólu? Empatyczne przestrzenie lektury, Łódź 2009, s. 80.

${ }_{18}$ Warto też dopowiedzieć: tak przeczytany liryk *** U szczytu antynomij byłby wyostrzeniem czy wzmocnieniem obrazu domykającego Odę III (powstałą w kwietniu 1967 r., zatem w zbliżonym czasie), gdzie Wat przekazuje swoją skórę na materiał do oprawy pośmiertnego tomu własnych wierszy. Dermo-manuskrypt z liryku o szynkarce i kowalu to - rzekłbym - spotęgowanie dermo-introligatorki z Ody III. Zob. A. Wat, op.cit., s. 203-206. 
Zauważmy jednak: rękopis, w którym Aleksander Wat zapisał po raz pierwszy wiersz o niesamowitym rękopisie, percypujemy tu, jak dotąd, wyłącznie za pośrednictwem transliteracji. Wiemy już dużo o zwerbalizowanym sensie utworu in statu nascendi, nie wiemy jeszcze nic o tym, jak wiersz - tak mocno podkreślający materialność niesamowitego zapisu - w swym pierwszym zapisie się zmaterializował. A przecież materialny wymiar Watowego pisania jest wyrazisty i różnorodny, o czym przekonuje sugestywny komentarz Jana Zielińskiego, znakomitego badacza i edytora tej twórczości. Samo tylko ,spectrum form” zapisu notatnikowego, właściwego autorowi Ciemnego świecidta, Zieliński tak oto charakteryzuje:

Od szorstkich szaroburych okładek i gąbczastego papieru zeszycików, w których Wat, jeszcze przed wyjazdem z Polski, zapisywał opowiadania i fraszki, przez brązowe skoroszyty z serii Despé ze stylizowaną wiewiórką, wydawane przez paryską firmę G. \& P. Deschamps, stustronicowe kołonotatniki z literkami NF - gwarancją francuskich norm jakości, piękne karminowe skoroszyty amerykańskie z wytłoczoną na okładce pozłacaną pieczęcią gwarancji i stylizowanym na gotyk napisem Collegeware, po notatnik kupiony w Palmie na Majorce i - włożony przez Olę Watową do teczki papeterii Joseph Gibert - ostatni, pożegnalny zeszyt, firmy Rhodia, w pomarańczowej okładce. Do tej różnorodności podłoża dodać trzeba rozmaitość przyborów piśmiennych - ołówków, wiecznych piór, długopisów. Zapiski Wata są różnokolorową mozaiką odcieni niebieskiego i granatu, zieleni, czerwieni, w różnych kombinacjach, którym towarzyszy skomplikowany system skrótów przy zapiskach bibliograficznych. [...] grafity łamały się, atrament wysychał, wypisywały się długopisy, darł się papier. Gorączkowa niekiedy praca myśli zderzała się często z oporem materii, kartki notatników Wata przypominają kolorowe mapy pól bitewnych ${ }^{19}$.

Jak zatem wygląda pierwszy rękopis wiersza o - przejmującym w swej materialności - rękopisie?

Spójrzmy na ilustrację 1: liryk *** U szczytu antynomij został napisany jasnoniebieskim atramentem na „kartce” szczególnego rodzaju - jest nią opakowanie lekarstwa o nazwie Glifanan. W archiwum wraz z pudełkiem-brulionem zachowała się także ulotka informująca o składzie, zastosowaniu oraz sposobie użycia medykamentu: Glifanan to silny lek przeciwbólowy, stosowany, między innymi, w bólowych chorobach neurologicznych. Czytelnicy Dziennika bez samogłosek wiedzą, iż podstawowym środkiem farmakologicznym, wspomagającym cierpiącego poetę $\mathrm{w}$ - niemożliwej do wygrania - walce $\mathrm{z}$ chorobą bólową, był lek o nazwie Percodan. Istotnie, całe akapity Dziennika bez samogłosek to relacje o działaniu (lub braku działaniu) Percodanu. Ślad stosowania Glifananu odnaleźć można natomiast w archiwum Wata, dokładniej - w stosunkowo obszernej dokumentacji medycznej, na którą składają się recepty, wyniki badań, wypisy ze szpitali, zalecenia lekarskie etc. Właśnie

19 J. Zieliński, Kłącza - (kłonice) - synapsy (Postowie) [w:] A. Wat, Notatniki, transkrypcja i oprac. A. Dziadek, J. Zieliński, Warszawa 2015, s. 902. 


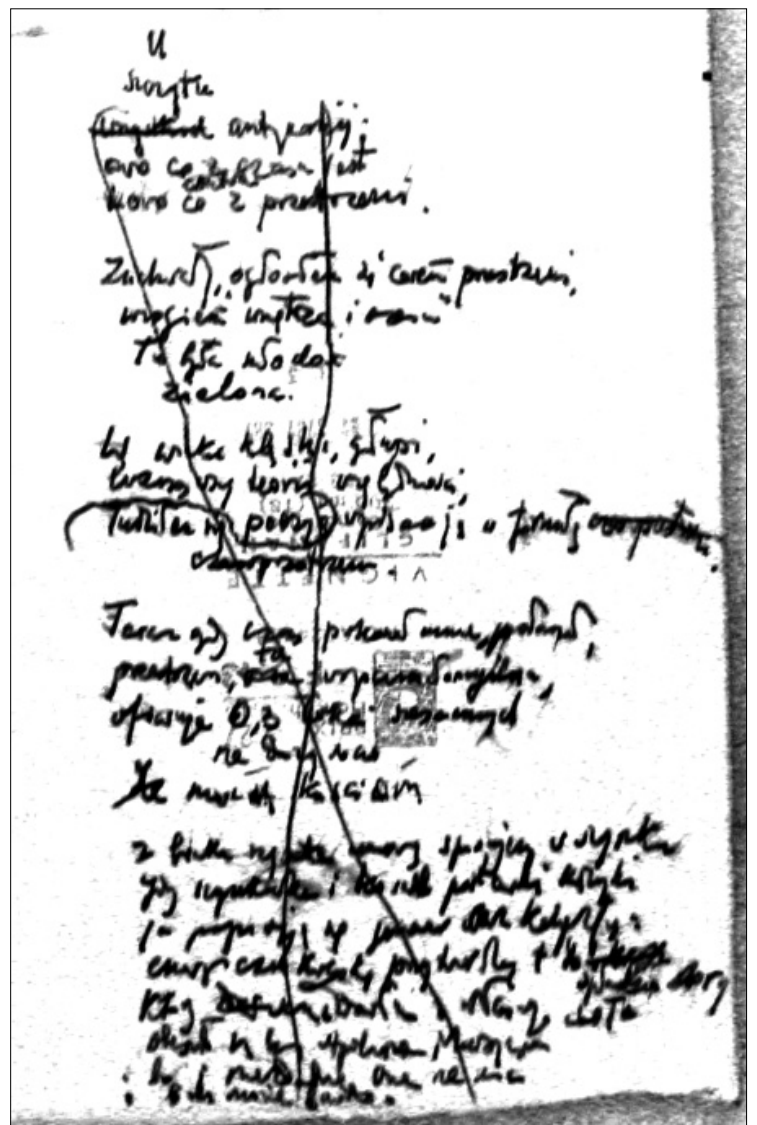

I1. 1. Pierwszy rękopis wiersza *** U szczytu antynomij, Beinecke Rare Book \& Manuscript Library, Yale University, Aleksander Wat Papers, GEN MSS 705, Series II Writings, Box 22, Folder 465

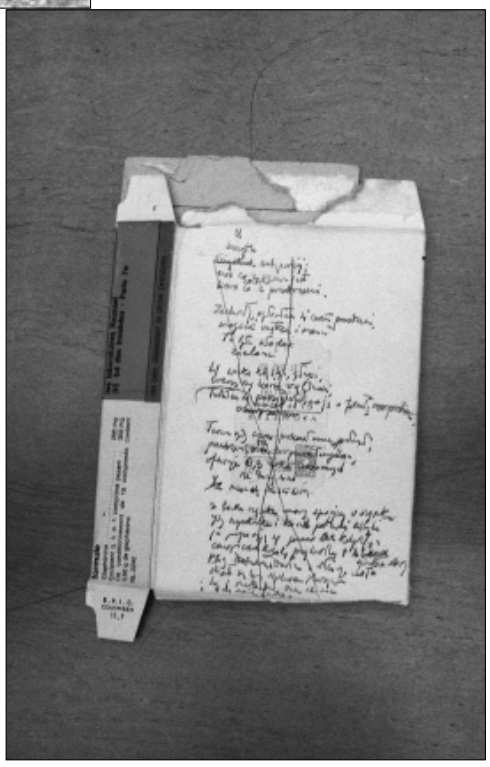


w tej kolekcji odnalazłem receptę na Glifanan, wypisaną przez francuskiego lekarza z datą: 29.04.1967 roku ${ }^{20}$. Datą, zauważmy, wcześniejszą o równe trzy miesiące od daty śmierci Aleksandra Wata.

Nie wiem, dlaczego poeta nakreślił pierwszy szkic wiersza na tak szczególnym nośniku. Nie była to - trzeba zastrzec od razu - jego standardowa procedura; w całym archiwum nie natknąłem się na podobny casus zaadaptowania jako nośnika przedmiotu pierwotnie służącego całkowicie odmiennym celom. Czy był to konceptualny gest twórczy, odegrany przed samym sobą, będący formą (auto)ironicznej gry z chorobą? Czy też ów dobór nośnika nie miał w sobie nic $\mathrm{z}$ tak pojmowanego gestu artystycznego, posiadał charakter czysto przypadkowy: akurat taki przedmiot, nadający się do zapisania, znalazł się pod ręką? Jakkolwiek było (lub nie było), pierwsza materialna postać wiersza koresponduje ze znaczeniami wyrażonymi za pomocą jego słów - tak to czytam, tak to widzę, tak to odczuwam. Między sensem ewokowanym werbalnie a fizjonomią zapisu zachodzi szczególnego rodzaju związek. Jaki? Spróbuję to dookreślić.

Po pierwsze: wiersz, który ustanawia obraz niesamowitego i makabrycznego manuskryptu, sam zapisany jest w manuskrypcie niezwykłym, nietypowym i - przepraszam za używanie silnych kwantyfikatorów - wstrząsającym, bo będącym świadectwem nieuleczalnej choroby bólowej. Utrwalając umowę o grób, zawartą między umierającym człowiekiem a przestrzenią, przyjmując w siebie sygnaturę człowieka, pudełko po Glifananie zastępuje niejako skórę poety, staje się jej substytutem, metonimiczną reprezentacją, materialnym ekwiwalentem symbolicznej wizji.

Po drugie: wiersz, który pseudonimuje za pomocą słów związek bólu i pisma, bolącego i piszącego ciała, związek ów zarazem unaocznia swą materialną postacią. Lekarstwo-brulion należy przecież do porządku choroby i porządku sztuki, jest tyleż częścią ,pokoju chorego”, ile „pracowni artysty”, rzec można, uzmysławia tożsamość tych dwu nakładających się na siebie miejsc, w których znajduje się cierpiąco-piszące i pisząco-cierpiące ,ja”.

Po trzecie wreszcie: wiersz o zamknięciu w ciasnej przestrzeni zapisany zostaje zminiaturyzowanym pismem w obrębie niewielkiego prostokącika (kilka na kilkanaście centymetrów), znacznie mniejszego od zwykłej kartki z zeszytu. Słowa wynotowane z młodzieńczego poematu prozą, wyrażające wiarę w nieograniczone możliwości przestrzennej ekspansji twórczego i wyzwolonego podmiotu, wpisane w wąskie ramy pudełka od przeciwbólowego lekarstwa stają się wizualizacją ironicznego napięcia między deklarowaną w Piecyku ... ,żądzą: uprzestrzenić się!" a kubaturą czekającego już na poetę grobu.

Powtórzę raz jeszcze: materialność tekstu współtworzy, stymuluje czy intensyfikuje sensotwórczą moc słów. Zależność tę opisać można za pomocą terminologii francuskiej, zaproponowanej przez Christiana Bonneta, a do polskiego literaturoznawstwa wprowadzonej przez Adama Dziadka, który tak oto przybliża sens zapożyczonego pojęcia:

${ }^{20}$ Beinecke Rare Book \& Manuscript Library, Yale University, Aleksander Wat Papers, GEN MSS 705, Series III Personal Papers and Memorabilia, Box 38, Folder 841. 
W ujęciu kognitywistycznym Somatekst (zapis tego terminu wielką literą stosuje Christian Bonnet) jest definiowany w kontekście typografii i komunikacji jako to, co nadaje Tekstowi formę drukowaną: rodzaj papieru, jego format, gramatura, kolor, odstępy, miejsca puste, układ na stronicy, typografia, kolory i ilustracje, rodzaj czcionki, a także kolory tła, liter, częstotliwość występowania ilustracji. Tekst jest zbiorem znaków typograficznych w druku, opiera się na znakach uporządkowanych w czasie i podlegających analizie lingwistycznej. Somatekst jest natomiast zbiorem sygnałów niejęzykowych postrzeganych za pomocą zmysłów i stanowiących ucieleśnienie Tekstu ${ }^{21}$.

Zgódźmy się na poszerzenie zakresu operacyjności tego pojęcia, odnieśmy je nie tylko do „formy drukowanej”, lecz także do przekazów rękopiśmiennych. Będziemy mogli wtedy powiedzieć, że ,somatekst pierwszego brulionu” mówi do nas dwoma głosami: głosem słów i głosem swojej „fizjonomii”. To samo powiedzieć można w kategoriach wyłożonych przez Bornsteina: wiersz Wata w swojej pierwszej brulionowej redakcji emituje znaczenia za pomocą - przede wszystkim - kodu lingwistycznego, a więc słów, zdań, wersów. Ale temu werbalnemu przekazowi wtóruje niejako kod bibliologiczny (wolę powiedzieć: materialny), czyli fizyczna realność brulionowego obiektu. Kod materialny potwierdza i wzmacnia komunikat, wyrażony za pomocą kodu lingwistycznego, a zarazem - kod lingwistyczny przykuwa uwagę do pewnych aspektów kodu materialnego ${ }^{22}$.

Mowa tu cały czas o materialności nośnika zapisu - ona bowiem jawi się jako szczególnie wyrazisty aspekt istnienia utworu - warto też jednak poświęcić nieco uwagi materialności samej inskrypcji. Przynajmniej w jednym elemencie zmusza ona do zastanowienia: co dokładnie wskazał poeta jako swoją sygnaturę naniesioną na zdartą z czoła skórę? W transliteracji przyjąłem, iż znakiem tym jest litera „t”. Można to wskazanie na literę ,t” rozumieć dwojako. Wyttumaczenie pierwsze: poeta podpisuje się jedynie ostatnią literą wyrazu „Wat”, wówczas mielibyśmy do czynienia $\mathrm{z}$ drugim i ostatnim już skróceniem nazwiska. Aleksander Chwat u progu swojej literackiej kariery (w „młodości durnej”) stał się Watem (zgłaszając niejako akces do nowoczesności, ale też siły, mocy), teraz zaś, u jej kresu (w „wieku klęski”, „gdy czas pokonał” go i „,połamał”) zostaje zeń już tylko - , ,"23. Wytłumaczenie drugie: na akcie umowy z prze-

${ }^{21}$ A. Dziadek, Projekt krytyki somatycznej, Warszawa 2014, s. 167-168.

${ }^{22}$ Sprawa tego niezwykłego ,pudełkowego brulionu” jest zresztą jeszcze bardziej złożona, niżby to wynikało z zawartej w niniejszym artykule interpretacji, a mianowicie: na tym samym pudełku od Glifananu, tyle tylko, że na jego odwrocie, Wat pracował także nad innym wierszem, niezwiązanym bezpośrednio (tekstologicznie) z utworem o „szczycie antynomij” i zaczynającym się od słów „Parobcy przedzierali się przez gąszcz paproci”. Pudełko jest więc $\mathrm{w}$ gruncie rzeczy brulionem podwójnym. W obecnej wersji moich rozważań kwestię tę jedynie sygnalizuję - do „tej kartki” Wata (i w ogóle do brulionów Wata) mam zamiar jeszcze powrócić w moich przyszłych, planowanych publikacjach.

${ }^{23}$ Za zwrócenie mojej uwagi na taki trop interpretacyjny uprzejmie dziękuję Panu Profesorowi Janowi Zielińskiemu. 
strzenią poeta podpisuje się pełnym imieniem i nazwiskiem, ale ostatnią literę w podpisie wyróżnia graficznie, dając, w przypływie próżności, ,,popis kaligrafii”. Obie możliwości rozumienia tego gestu wydają mi się równie uzasadnione, żadna z nich nie jest jednak wystarczająca, jeśli bowiem przyjrzymy się uważnie rękopisowi, to okaże się, że sposób zapisania owego „t” jest cokolwiek dziwny. Ostatnia litera nazwiska ,(Ch)Wat” przypomina mianowicie - mały znak krzyża. Zauważmy konsekwencję: podpisy niepiśmiennych świadków aktu notarialnego i ,kaligraficzny” podpis pisarza, przeciwstawione sobie retorycznie (por. figura opozycji: ,gdzie szynkarka i kowal postawili krzyżyk / tam ja próżny dałem popis kaligrafii”), równocześnie upodabniają się pod względem graficznym. Czyżby Wat chciał w ten sposób wzmocnić, zintensyfikować grę z symboliką chrześcijańską, pośrednio zaś - grę z sensem pasyjnym? Czy podpisy-krzyżyki postawione przez szynkarkę i kowala oraz podpis-litera-krzyżyk postawiony przez poetę są znakami przywołującymi chrześcijańską opowieść o męce, śmierci i jej soterycznym wymiarze? A jeśli przywołującym - to w jakim celu? By stwierdzić, że opowieść ta objaśnia, nadaje sens beznadziejnym aspektom ludzkiej egzystencji (a więc na przykład: cierpiący człowiek łączy się z ofiarą Chrystusa), czy, przeciwnie, by wykazać, że opowieść ta niczego nie czyni zrozumiałym, cierpienie pozostaje wyłącznie doświadczeniem destrukcyjnym i przeklętym (a więc: „krzyżyk” jest znakiem pustym, niezdolnym odnieść nas do żadnego horyzontu nadziei)? Wszystkie te pytania uruchamia, jak sądzę, nieoczywistość graficznego kształtu jednego elementu inskrypcji.

Teraz, gdy wiemy już, jaką postać przybrała pierwsza inkarnacja (czy preinkarnacja) wiersza, gdy postać tę zdołaliśmy już wielostronnie i wieloaspektowo opisać, możemy postawić pytanie: co działo się z tym pisanym i przepisywanym tekstem - dalej?

b) Odsłona druga

Drugi chronologicznie rękopis utworu ${ }^{24} \mathrm{w}$ swej transliteracji przedstawia się następująco:

$$
\begin{gathered}
\text { U } \\
\text { szczytu } \\
\text { antynomij: } \\
\text { owo co z czasu jest } \\
\text { contra } \\
\text { owemu co z przestrzeni. }
\end{gathered}
$$

Zuchwały, „ogłosiłem się carem przestrzeni, wrogiem wnętrza i czasu".

To była młodość

durna.

zielona.

${ }^{24}$ Lokalizacja dokumentu: Beinecke Rare Book \& Manuscript Library, Yale University, Aleksander Wat Papers, GEN MSS 705, Series II Writings, Box 31, Folder 740, s. 10-11. 


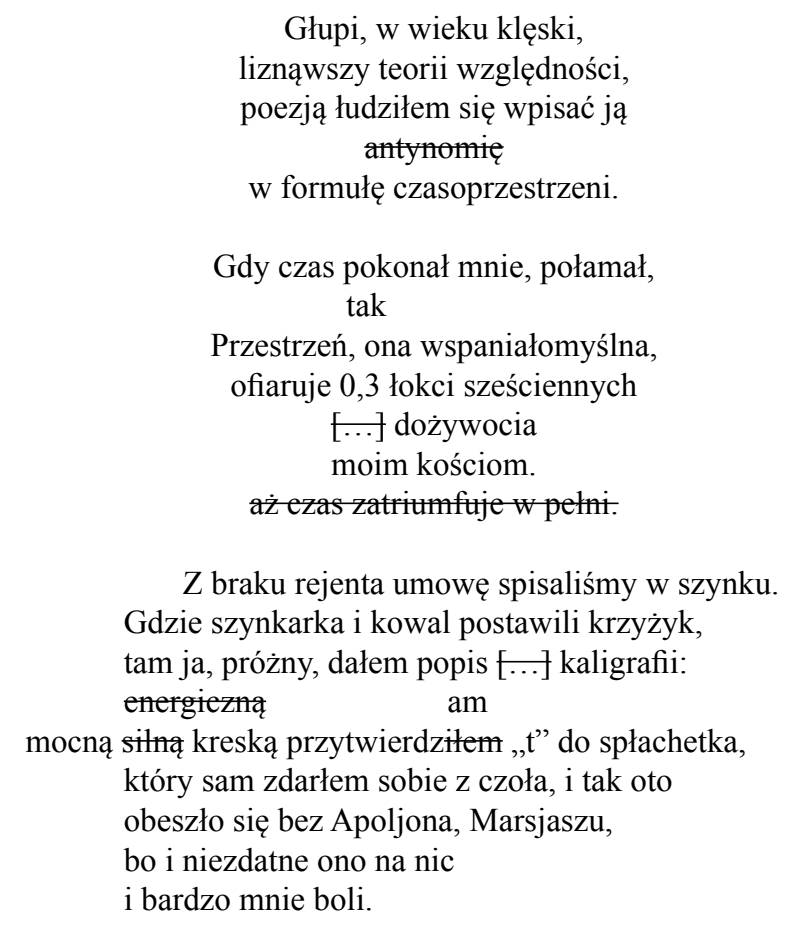

Wniosek, jaki płynie z porównania transliteracji rękopisu drugiego z transliteracją rękopisu pierwszego, prowadzi - jak sądzę - do jednej konkluzji zasadniczej. Kod lingwistyczny utworu zmienia się w procesie transmisji tekstu z nośnika na nośnik, podlega także przekształceniom w toku rewizji, jakiej poddana zostaje wersja druga - ale zmiany te są niewielkie, pozbawione zasadniczych konsekwencji interpretacyjnych. Wat pracuje nad doborem spójników, zmienia końcówki fleksyjne i koniugacyjne oraz zaimki, zdarza mu się mnożyć konkurencyjne wersje jednego epitetu (acz nie bardzo intensywnie, por. brulion II i szukanie określenia dla „kreski” w strofie piątej). Gdybym miał wyróżnić dwa najciekawsze interpretacyjnie „drgnięcia” tekstu, wskazałbym najpierw na to miejsce:

Brulion I, strofa druga

Zuchwały, „ogłosiłem się carem przestrzeni, wrogiem wnętrza i czasu" To była młodość zielona.
Brulion II, strofa druga

Zuchwały, „ogłosiłem się carem prze-

wrogiem wnętrza i czasu".

To była młodość

durna.

zielona.

strzeni,

W brulionie I strofa druga nie zawierała jeszcze odniesienia do Mickiewiczowskiego intertekstu; intertekst ów przywołany był dopiero w strofie 
trzeciej (por. „głupi /w wieku klęski”). W brulionie II natomiast aluzja zostaje wprowadzona „wcześniej”, już w strofie drugiej. Nie od razu jednak, nie w pierwszym zetknięciu długopisu z kartką, lecz w toku rewizji pierwszego zapisu. Wówczas bowiem powtórzony pierwotnie za brulionem I epitet ,zielona” ulega skreśleniu i zastąpieniu przez dopisane w interlinii „lozańskie” określenie młodości ${ }^{25}$.

Inne warte podkreślenia zjawisko zachodzące w brulionie II wiąże się z pracą nad strofą czwartą:

Gdy czas pokonał mnie, połamał, tak

Przestrzeń, ona wspaniałomyślna, ofiaruje 0,3 łokci sześciennych

[...] dożywocia

moim kościom.

aż ezas zatriumfuje w pełni.

„Tryumfem czasu” jest, rzecz jasna, rozkład ludzkich kości: gdy zniknie ostatni ślad po człowieku, który pysznił się swoim rzekomym zwycięstwem nad ograniczeniami czasu i przestrzeni, czas i przestrzeń będą trwały nadal. Ostatecznie Wat rezygnuje jednak z tego dopowiedzenia (być może uznając, że motyw tryumfu czasu i obrócenia w proch szkieletu kryje się już w metaforze „dożywocia kości” i w wyraźnym zaznaczeniu, iż darowizna grobu nie jest wieczysta).

Ale nawet te dwa - najbardziej wyraziste interpretacyjnie - przypadki nie zmieniają faktu, że skala semantycznej wariancji tekstu pozostaje nierozległa. Inaczej mają się sprawy, gdy weźmiemy pod uwagę to, co w procesie transmisji dzieje się z kodem materialnym wiersza in statu nascendi. Spójrzmy na ilustrację 2 .

W swym drugim brulionowym ,wcieleniu” wiersz jest nadal inskrypcją odręczną, sporządzoną niebieskim atramentem. Aluzyjny zapis litery „„” przybrał jeszcze na intensywności: ostatnia litera właściwie staje się krzyżem. Przy tym wszystkim jednak oczywistej standaryzacji podlega nośnik: drugi brulion to zwyczajny notatnik (typu „kołozeszyt”) o żółtych, kratkowanych stronach. Dysponując znacznie rozleglejszą przestrzenią zapisu, Wat nie dąży już do miniaturyzacji pisma, nie usiłuje też zmieścić całego tekstu między krawędziami kartki: utwór rozkłada się na stronie recto oraz verso.

To wszystko, jak sądzę, streścić można następującą formułą: kod materialny w pewnej mierze ,odkleił się” od kodu lingwistycznego, przestał z nim „współgrać”. Nie eksponuje już związku pisma i bólu, nie wizualizuje napię-

${ }^{25}$ Nawiązanie do liryków lozańskich pojawia się u Wata nie tylko w tym utworze. Na istnienie takich odniesień w innych wierszach zwracali uwagę komentatorzy. Por. M. Stala, W stronę Lemanu [w:] idem, Chwile pewności. 20 szkiców o poezji i krytyce, Kraków 1991, s. 25; K. Pietrych, op.cit., s. 89. 


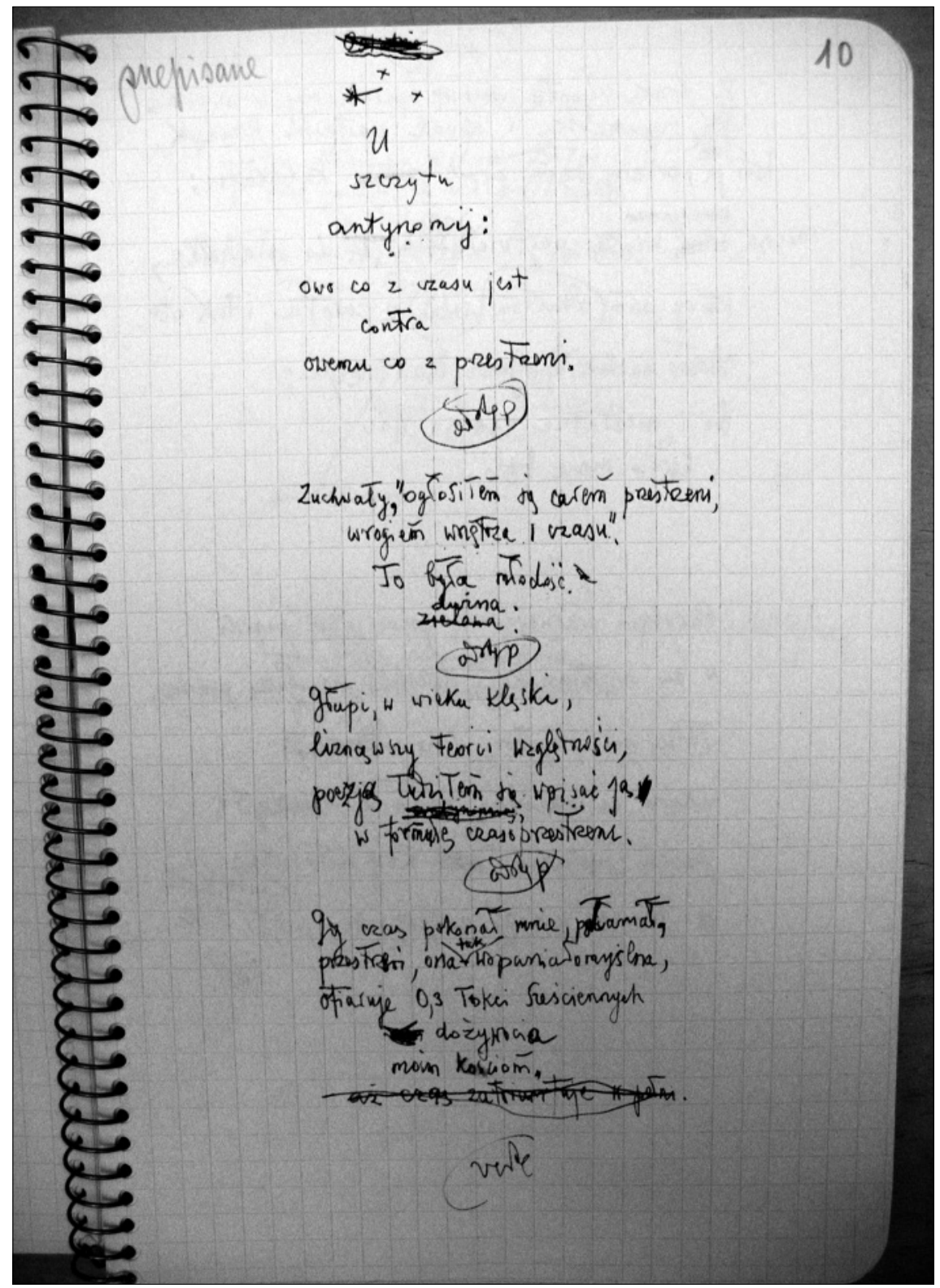

Il. 2a. Drugi rękopis wiersza *** U szczytu antynomij, Beinecke Rare Book \& Manuscript Library, Yale University, Aleksander Wat Papers, GEN MSS 705, Series II Writings, Box 31, Folder 740, s. 10 


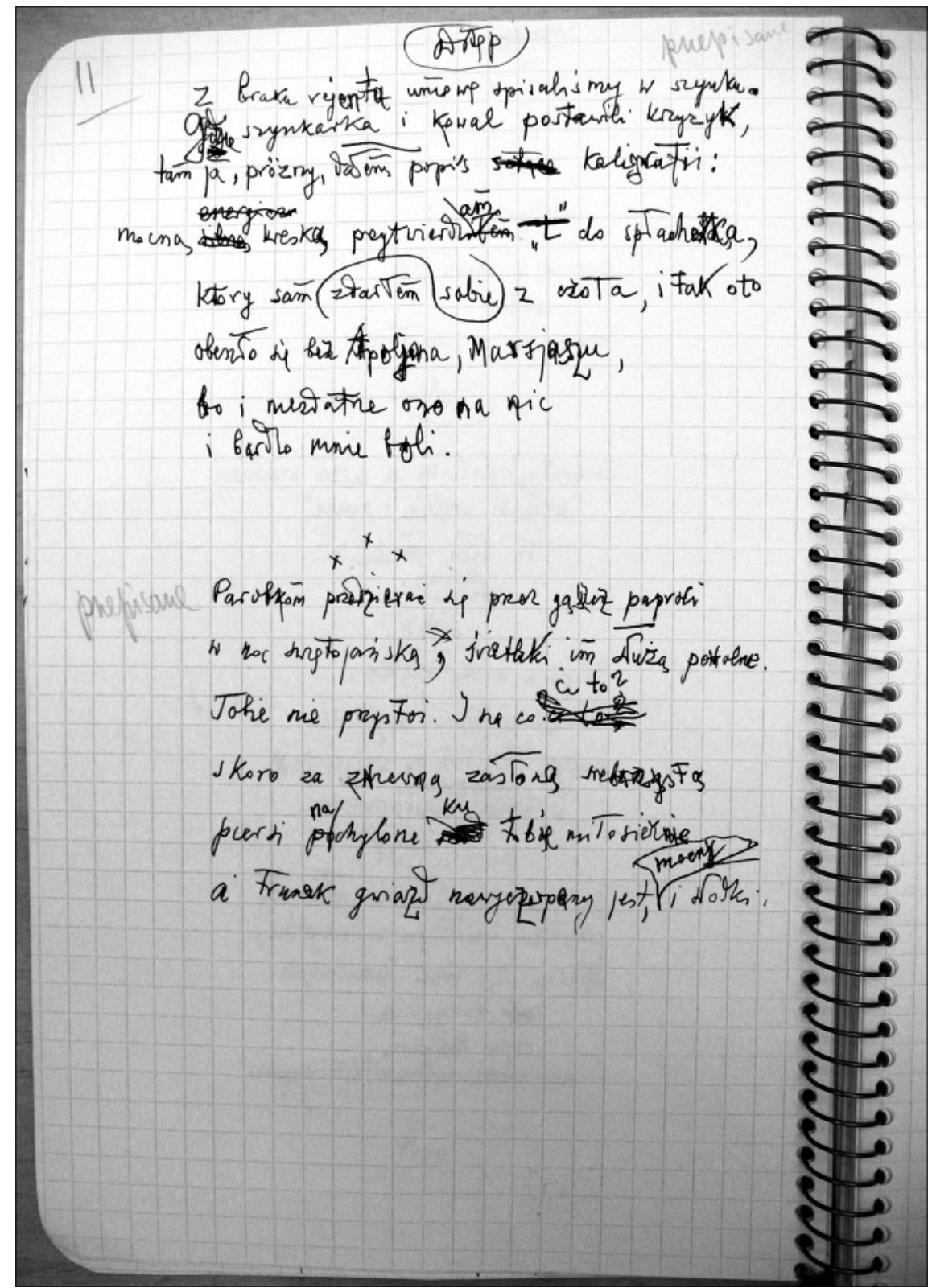

Il. 2b. Drugi rękopis wiersza *** U szczytu antynomij, Beinecke Rare Book \& Manuscript Library, Yale University, Aleksander Wat Papers, GEN MSS 705, Series II Writings, Box 31, Folder 740, s. 11 
cia między cytatem z niegdysiejszego „,monologu woli i mocy”26 („Ogłosiłem się carem przestrzeni / wrogiem wnętrza") a kondycją słabego podmiotu i czekającym nań grobem o kubaturze „0,3 łokci sześciennych”27.

c) Odsłona trzecia

Ostatnim zachowanym i odnalezionym przeze mnie w archiwum dokumentem procesu tekstotwórczego jest maszynopis ${ }^{28}$. Tradycyjnie już analizę $\mathrm{i}$ interpretację rozpoczniemy od transliteracji.

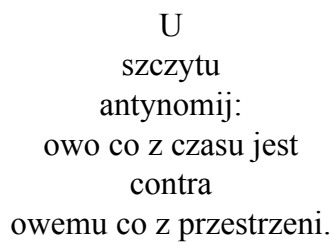

Zuchwały, „ogłosiłem się carem przestrzeni, wrogiem wnętrza i czasu".

To była młodość durna.

Głupi, w wieku klęski, liznąwszy teorii względności poezją łudziłem się wpisać ją $\mathrm{w}$ formułę czasoprzestrzeni.

Gdy czas pokonał mnie, połamał, Przestrzeń, ona tak wspaniałomyślna, ofiaruje 0,3 łokci sześciennych dożywocia moim kościom.

$\mathrm{Z}$ braku rejenta umowę spisaliśmy w szynku. Gdzie szynkarka i kowal postawili krzyżyk, tam ja, próżny, dałem popis kaligrafii: mocną kreską przytwierdzam $t$ do spłachetka, który sam sobie zdarłem $\mathrm{z}$ czoła, i tak oto obeszło się bez Apoljona, Marsjaszu, bo i niezdatne ono na nic i bardzo mnie boli.

${ }^{26}$ Nawiązuję tu do określenia użytego przez Michała Głowińskiego, a odnoszącego się do poezji Leopolda Staffa i Juliana Tuwima (zob. M. Głowiński, Poetyka Tuwima a polska tradycja literacka, Warszawa 1962).

27 „Łokieć sześcienny”, dodajmy, to miara objętości stosowana w systemie metrycznym Królestwa Polskiego w latach 1819-1849 (1 łokieć sześcienny to około 0,19 metra sześciennego).

${ }^{28}$ Lokalizacja dokumentu: Beinecke Rare Book \& Manuscript Library, Yale University, Aleksander Wat Papers, GEN MSS 705, Series II Writings, Box 22, Folder 482. 
Gdy porównamy redakcję tekstu ustaloną ostatecznie w rękopisie II (to jest tę, która wyłania się po uwzględnieniu kilku skreśleń, substytucji i addycji) $\mathrm{z}$ redakcją przyjętą $\mathrm{w}$ maszynopisie, to okaże się, że są one identyczne co do najmniejszego drobiazgu interpunkcyjnego. Kod lingwistyczny pisanego i przepisywanego tekstu został bez uszczerbku przeniesiony. Co oczywiste, modyfikacji zasadniczej uległ jednak - znów - kod materialny.

Trzecia inkarnacja tekstu przynosi jego dalszą materialną przemianę. Wiersz niemal definitywnie przestaje być odręczną inskrypcją. Niemal, bo w jednym jedynym miejscu pojawia się manuskryptowa adnotacja. A miejsce to szczególne. Otóż w zapisie maszynowym uczyniona została, bez wątpienia celowo, luka.

mocną kreskę przytwierdzam do spłachetka

który sam sobie zdarłem z czoła

W lukę tę następnie dopisany został odręcznie znak (zob. il. 3). Spośród wszystkich „sygnatur" ta wydaje się najmniej graficznie oczywista i, prawdę mówiąc, nie jestem pewien, co właściwie zostało tu odręcznie naniesione. Przypuszczam, że pierwotnie - tak jak w rękopisie II - poeta dopisał powiększoną, stylizowaną literę „t”, potem jednak (powtarzam, to tylko domysł) skreślił dolny ,zawijas laseczki”, zamieniając w ten sposób literę-krzyżyk w krzyżyk, rzec można - ujednoznaczniając znak. Być może najciekawsza jest tu jednak nie tyle identyfikacja sygnatury, ile sam fakt jej ręcznego dopisania na dokumencie sporządzanym przecież w sposób mechaniczny. Kombinacja pisma maszynowego i ręcznego daje efekt zaskakujący, niezwykły: wygląda to tak, jakby Wat powtarzał, odgrywał niejako opisany w wierszu gest sygnatury. Jakby, czytając własny wiersz, spełniał wpisany weń scenariusz, stawał się aktorem reżyserowanego przez siebie spektaklu. Wyobrażony w wierszu podpis zostaje wykonany zarazem ,na niby” i ,naprawdę”: na niby, bo przecież jego nośnikiem nie jest zdarta z czoła skóra, lecz papier; naprawdę, bo sygnatura jest własnoręczna i starannie stylizowana. Przede wszystkim zaś: podpis jest prawdziwy, bo prawdziwa jest bezradność podmiotu, pozbawionego złudzeń i oczekującego na - rzeczywisty - grób.

d) Odsłona czwarta (jak dotąd - ostatnia)

Utwór - pisany najpierw na pudełku od leku przeciwbólowego, później przeniesiony do notatnika, następnie zaś do maszynopisu - nie został opublikowany za życia autora, nie znalazł się również w ogłoszonym pośmiertnie (lecz przez poetę planowanym) Ciemnym świecidle (1968). Wiersz ten nie pojawia się wśród ineditów zawartych w tomie Poezje, opracowanym przez Annę Micińską i Jana Zielińskiego (1997) i należącym do serii Pism zebranych. Do druku liryk trafił późno, przeszło trzydzieści lat po swoich narodzinach - w roku 2009. Stało się to dzięki Adamowi Dziadkowi, który tekst odnalazł w amerykańskim archiwum Wata i ogłosił na łamach ,Zeszytów Literackich”29.

29 „Zeszyty Literackie” 2009, nr 108, s. 7-8. 


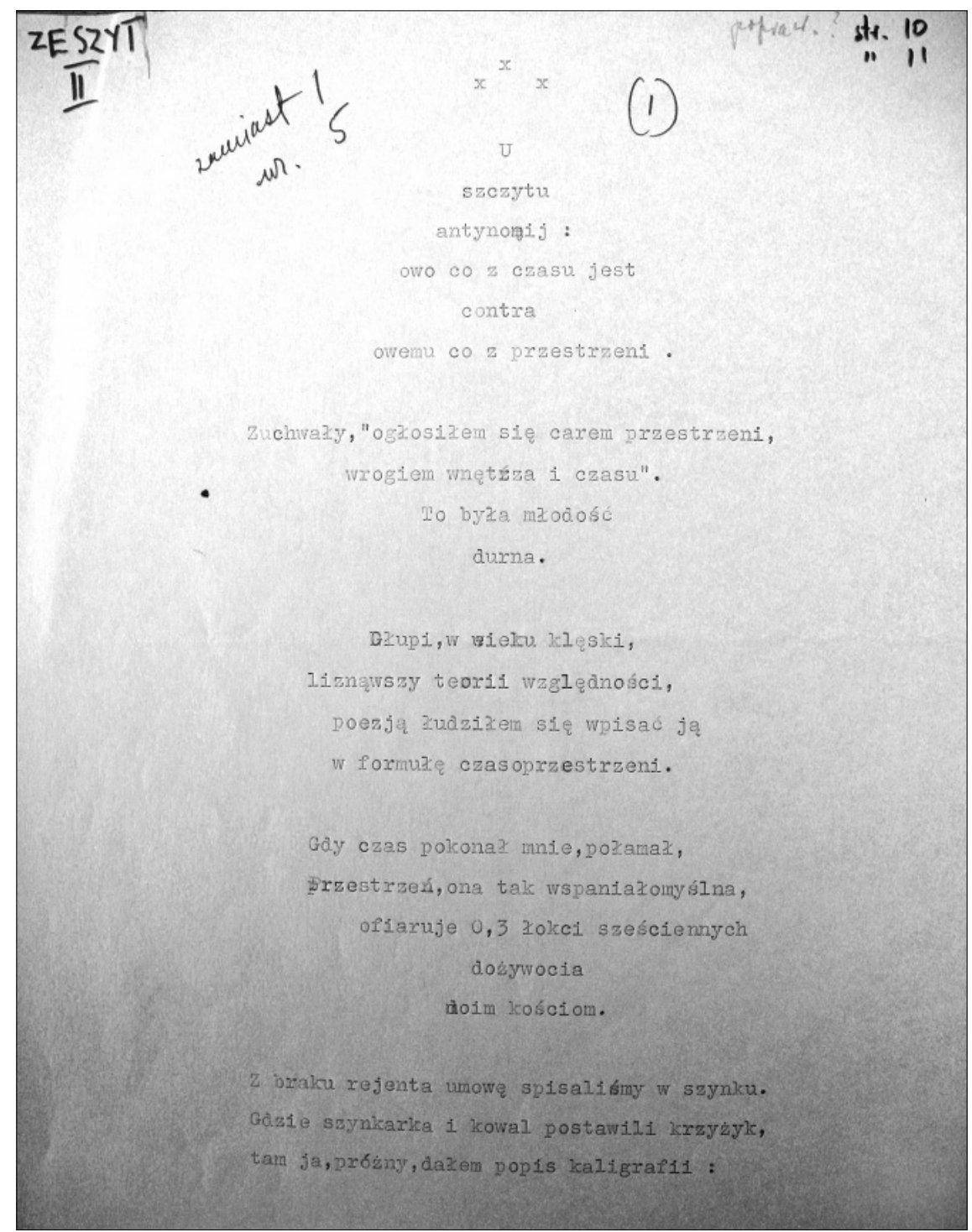

Il. 3a. Maszynopis wiersza *** U szczytu antynomij, Beinecke Rare Book \& Manuscript Library, Yale University, Aleksander Wat Papers, GEN MSS 705, Series II Writings, Box 22, Folder 482 


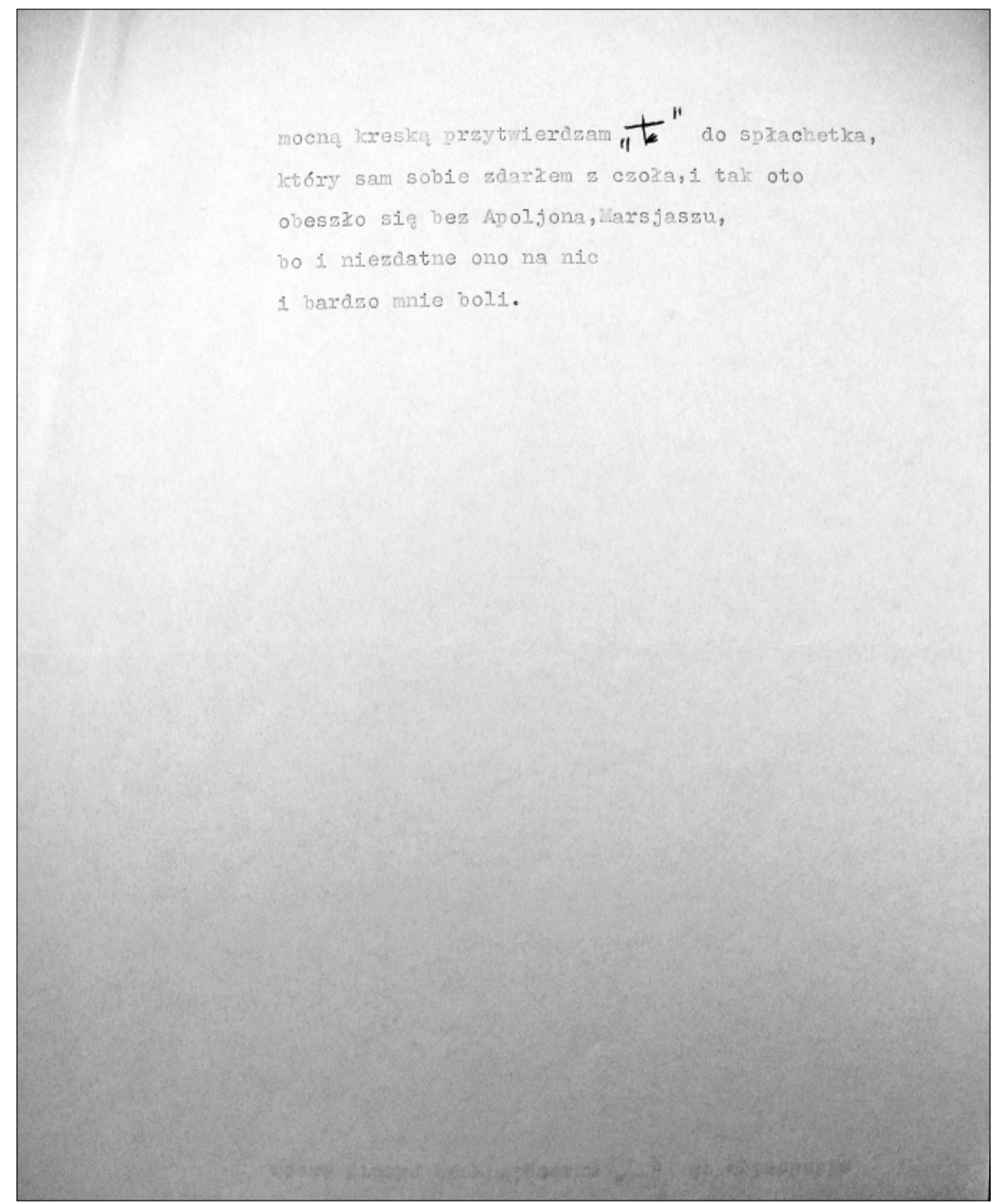

Il. 3a. Maszynopis wiersza *** Uszczytu antynomij, Beinecke Rare Book \& Manuscript Library, Yale University, Aleksander Wat Papers, GEN MSS 705, Series II Writings, Box 22, Folder 482 
W pierwodruku drobnym przemianom uległ - znów - kod lingwistyczny. Uwagę zwraca przede wszystkim jedna różnica wobec znanych mi autorskich przekazów tekstu: rzeczownik „,czas” w wersie czwartym pojawia się nie w dopełniaczu (jak w obu rękopisach i maszynopisie), lecz w narzędniku.

$$
\begin{gathered}
\text { U } \\
\text { szczytu } \\
\text { antynomij: } \\
\text { owo co z czasem jest } \\
\text { contra } \\
\text { owemu co z przestrzeni. } \\
\text { Zuchwały, „ogłosiłem się carem przestrzeni, } \\
\text { wrogiem wnętrza i czasu”. } \\
\text { To była młodość } \\
\text { Durna. } \\
\text { Głupi, w wieku klęski, } \\
\text { liznąwszy teorii względności, } \\
\text { poezją łudziłem się wpisać ją } \\
\text { w formułę czasoprzestrzeni. } \\
\text { Gdy czas pokonał mnie, połamał, } \\
\text { Przestrzeń, ona tak wspaniałomyślna, } \\
\text { ofiaruje 0,3 łokci sześciennych } \\
\text { dożywocia } \\
\text { moim kościom. }
\end{gathered}
$$

$\mathrm{Z}$ braku rejenta umowę spisaliśmy w szynku.

Gdzie szynkarka i kowal postawili krzyżyk,

Tam ja, próżny, dałem popis kaligrafii:

mocną kreską przytwierdzam „," do spłachetka, który sam sobie zdarłem z czoła i tak oto obeszło się bez Apoljona, Marsjasza, bo i niezdatne ono na nic i bardzo mnie boli.

Pierwodruk na łamach „Zeszytów Literackich” zmienił też, co oczywiste, kod materialny. Utwór stał się tekstem wyłącznie już „mechanicznie reprodukowanym”, wytworzonym w całości „,pod ołowianej litery urzędem”, stracił ostatni ślad swej pierwotnej manuskryptowości, czyli sygnaturę, nawet na etapie maszynopisu wciąż jeszcze ręcznie wykonywaną. 


\section{Auratyczność rękopisu?}

Tak oto historia liryku *** U szczytu antynomij okazuje się historią tekstu zarazem stabilnego i poddanego radykalnym przeobrażeniom. Wiersz - pokonując drogę wiodącą od pudełka-kartki, przez kartkę notatnika, kartkę maszynopisu aż do kartki w piśmie literackim - zmienia się nieznacznie w zakresie kodu lingwistycznego, gruntownie natomiast pod względem kodu materialnego. Można tu nawet mówić o niemal całkowitym ,przekodowaniu” tekstu. Proces ów posiada, jak sądzę, co najmniej dwie konsekwencje semantyczne.

Po pierwsze, na każdym etapie swego istnienia - w pudełkowym brulionie, w notatnikowym manuskrypcie, w maszynopisie, wreszcie w edycji dokonanej po latach przez Adama Dziadka - wiersz Wata „mówi swoimi słowami” o związku bólu i pisma oraz o fiasku zdobywczych ambicji podmiotu, o jego zamknięciu w ciasnej, unieruchamiającej, opresywnej przestrzeni grobu. Ale jedynie w pierwszym brulionie mówi o tym wszystkim nie tylko „swoimi słowami”, lecz także swoją naocznością, swoją plastyczną formą.

Po drugie, proces transmisji, uwieńczony, jak dotąd, pierwodrukiem czasopiśmienniczym, może być opisany jako proces stopniowej dematerializacji autorskiej sygnatury. Co składa się na „Watowską sygnaturę” utworu zapisanego na opakowaniu lekarstwa przeciwbólowego? Niewątpliwie jego auto-graficzność, fakt zapisania ręką poety. Ale też, właśnie, nadanie funkcji nośnika przedmiotowi bezpośrednio związanemu z codziennym życiem poety, z jego - chorobą naznaczoną - egzystencją. Gdy tekst „,przewędrował” z opakowania do notatnika, materialnym śladem cielesności „piszącego ja” pozostała już tylko sama odręczna grafia. W maszynopisie także i ten element zanikł niemal doszczętnie - niemal, bo jednak, przypomnijmy, Wat złożył na „graficznie bezosobowej” karcie swój odręczny podpis, pozostawił ślad ręki, jakby wiedziony intencją podtrzymania związku tekstu i ciała. Definitywny kres tym formom „uobecnienia ja” (ktoś inny zechce może powiedzieć - tym próbom czy pozorom „uobecnienia ja”; to już kwestia z zakresu filozofii reprezentacji) kładzie dopiero edycja pierwodrukowa, gdzie nośnik i kształt zapisu, poddane procedurom standaryzacji, nie odsyłają w żaden sposób do somatycznej realności piszącego podmiotu. To prawda, wiersz z „Zeszytów Literackich” nie jest ogołocony z „Watowskiej sygnatury” - zawiera przecież takie jej elementy, jak formalny autocytat czy też liczne odniesienia autobiograficzne, tyle że autorska sygnatura, wcześniej zarówno „materialna”, jak i ,językowa”, zachowuje teraz wyłącznie ów drugi aspekt czy wymiar. W języku Georga Bornsteina możemy powiedzieć: jedynie utwór w pierwszym brulionie wyraża doświadczenia somatyczne cierpiącego podmiotu za pomocą kodu materialnego.

Oczywiście, ów proces transmisji - jak próbowałem pokazać: w istotny sposób modyfikujący status tekstu, choć zmieniający w nim ledwie kilka słów - postępował zgodnie $\mathrm{z}$ wolą autora. To autor przepisał tekst z pudełka do notatnika, rozrywając pierwotny związek słów i formy ich zapisu. Nie zapo- 
minam o tym. Nie twierdzę również, że wiersz w postaci pierwodrukowej, tak już bardzo oddalony od pierwotnego kodu materialnego, pozbawiony został nośności, siły oddziaływania, intensywności. Przeciwnie, wiersz z ,Zeszytów Literackich" jest sam w sobie (to znaczy: bez odniesienia do swych prepublikacyjnych inkarnacji) ciekawy, istotny i, po prostu, przejmujący jako ekspresja doświadczenia traumatycznego. „W poezji polskiej zdarzył się cud pełnej podmiotowej obecności człowieka cierpiącego" - powiada Wojciech Ligęza ${ }^{30}$. Konstatacja krakowskiego badacza, afirmująca tak zdecydowanie poświadczającą i uobecniającą moc języka, dotyczy wierszy „w stanie czystym”, bytów słowno-symbolicznych, nie zaś ich rękopisów. Można ją powtórzyć, czytając wiersz *** U szczytu antynomij na łamach „Zeszytów Literackich”, nie wiedząc nic o formie i materii pierwszego brulionu.

Tak, to wszystko prawda. Która jednak nie zmienia psychologicznego faktu: mój osobisty odbiór Watowego liryku został trwale nawiedzony wizualnością, dotykalnością, najkrócej mówiąc, realnością „tej kartki” - tej jedynej w swoim rodzaju ,kartki-pudełka”. Ilekroć czytam wiersz wydrukowany na stronach „Zeszytów Literackich”, wraca do mnie ta pierwsza postać tekstu. Widząc standardowe, równe rzędy czarnych, drukowanych liter, „widzę” pudełko leku przeciwbólowego, pokryte jasnoniebieskim atramentem - tę metonimię skóry zdartej z bolącego czoła, tę inscenizację związku cierpienia i pisania, tę wizualizację zamknięcia w ciasnej przestrzeni.

Intensywność, z jaką ów szczególny rękopis narzuca się mojej wyobraźni, mógłbym - za Bornsteinem - opisać przy użyciu Benjaminowskiej kategorii ,auratyczności”. Przypomnijmy passusy z najsławniejszego eseju Waltera Benjamina - passusy cytowane i użyte przez amerykańskiego badacza „materialnego modernizmu":

Nawet przy najdoskonalszej reprodukcji nie ma mowy o jedynym, niepowtarzalnym związku dzieła sztuki z miejscem i czasem jego istnienia. [...]

Więź oryginału z miejscem i czasem jego istnienia składa się na pojęcie autentyczności. [...]

Okoliczności, w jakich może się znaleźć produkt reprodukcji technicznej, mogą zresztą nie naruszać egzystencji dzieła sztuki, niemniej pozbawiają pierwotnego znaczenia nierozerwalny związek z miejscem i czasem jego istnienia. [...]

Zatraca się tutaj coś, co się streszcza w pojęciu aury, słowem: to, co obumiera w epoce technicznej reprodukcji dzieła sztuki, to jego aura ${ }^{31}$.

Pierwotnym ,tu” tego wiersza, jego pierwotnym ,miejscem” jest - pudełko. W nim czy na nim ów wiersz powstawał, po raz pierwszy zaistniał. Poddany regułom standardowej typografii, wydrukowany, rozpowszechniony, traci swą ,auratyczność” (niczym stary obraz, będący pierwotnie integralną częścią

30 W. Ligęza, „Homo patiens” Aleksandra Wata, „Znak” 1991, nr 2.

31 W. Benjamin, Dzieło sztuki $w$ dobie reprodukcji technicznej, przeł. J. Sikorski [w:] idem, Aniot historii. Eseje, szkice, fragmenty, wybór i oprac. H. Orłowski, Poznań 1996, s. odpowiednio 204, 205, 206, 207. 
kaplicy, potem zaś przeniesiony z niej do muzealnego wnętrza). Traci - chcę to podkreślić bardzo mocno - w moim odbiorze, w moim odczuciu, w mojej lekturze. Gdy piszę o ,aurze rękopisu” (tego konkretnego rękopisu) i jej zaniku w klasycznej edycji, definiuję jedynie własny rodzaj wrażliwości na tekst (ten konkretny tekst), nie usiłując formułować żadnych uogólnionych praw z zakresu psychologii percepcji czy estetyki.

Sformułować mógłbym natomiast projekt nowej edycji wiersza - nie polemicznej wobec edycji papierowej, lecz (to także bardzo mocno podkreślam) komplementarnej. Byłaby to digitalna edycja genetyczna, udostępniająca on-line tekst we wszystkich kolejnych stadiach jego powstawania i istnienia. Rękopisy pojawiałyby się w niej w postaci obrazów (dających się powiększać, kadrować) oraz towarzyszących im transliteracji. Zamiast jednej, dominującej postaci tekstu otrzymalibyśmy wgląd w serię ,równouprawnionych” tekstowych inkarnacji, zobaczylibyśmy historię przemian kodu lingwistycznego i kodu bibliologicznego.

Inna sprawa, czy taka edycja istotnie pozwalałaby na doświadczanie ,auratyczności rękopisu". Jeśli wierzyć autorowi Dzieła sztuki w dobie reprodukcji technicznej - raczej nie. Pierwszy brulion, zdigitalizowany i udostępniony, stałby się przecież nieuchronnie jeszcze jednym obrazem w rozplenionej, globalnej mgławicy obrazów poddanych ,reprodukcji” potencjalnie nieskończonej - i jakże łatwej. Jedno kliknięcie pozwalałoby odtąd wyświetlić na ekranie komputera czy tabletu - natychmiast i w dowolnym miejscu na Zie$\mathrm{mi}$ - technicznie doskonały wizerunek przedmiotu pierwotnie tak intymnego, jak intymne być może przedśmiertne świadectwo cierpienia i tworzenia, bólo-pisania i pisanio-bólu. „Somatekst” brulionowego wiersza - zwielokrotniony, nieograniczenie udostępniony i zamieniony w obiekt wirtualny - uległby poniekąd dematerializacji, mimo że (właśnie dlatego że) na ekranie komputera moglibyśmy, dzięki wysokiej rozdzielczości obrazu, oglądać najdrobniejsze nawet szczegóły jego fizjonomii.

Może więc w poszukiwaniu aury rękopisu (tego konkretnego rękopisu i w ogóle rękopisu) powinniśmy ,pielgrzymować” do miejsca, gdzie „tę kartkę" weźmiemy do ręki? A więc, w tym przypadku, do Beinecke Rare Book \& Manuscript Library, Yale University, New Haven CT, USA? Zapewne, da się w taką podróż uwierzyć. Nawet jednak wówczas, gdy w poszukiwanie aury uwierzymy, podróż do źródła może skończyć się subiektywnie doznaną porażką (niczym ,pielgrzymka” bohatera jednego z Herbertowskich wierszy do oryginału Mona Lisy). Jak zauważa Bornstein w innym miejscu swojej książki o materialnym modernizmie, „czytelnia zbiorów rzadkich” nie jest neutralnym kontekstem lektury, lecz specyficznym uwarunkowaniem percepcji, przemieniającym oglądane i dotykane papiery w „cenne artefakty starannie konserwowane przez instytucje" służące udostępnianiu dóbr kultury ${ }^{32}$. Powiedzieliśmy wcześniej, że edycja internetowa może być zinterpretowana jako

${ }^{32}$ G. Bornstein, Material Modernism. The Politics of the Page, New York 2001, s. 64 (przeł. M.A.). 
udostępnienie oryginału, które jednak niweczy jego ,aurę”; z innego punktu widzenia ,aura" jest już jednak stracona nieodwołalnie z chwilą, gdy rękopis zwłaszcza rękopis będący materialną cząstką dramatycznej ludzkiej biografii - przestaje należeć do żywej pracowni pisarza, a staje się „zbiorem rzadkim”.

Ostatecznie jednak nie (psychologiczna w gruncie rzeczy, mocno subiektywna) kwestia „auratyczności rękopisu” interesuje mnie tu najbardziej. Zamiast melancholijnej puenty, mówiącej o zaniku aury, proponuję więc inne, bardziej chyba konstruktywne, dopowiedzenie końcowe.

\section{„The Politics of the Page” i „critique génétique”: w stronę wspólnej narracji}

The Politics of the Page Georga Bornsteina i francuska critique génétique - te dwa projekty literaturoznawcze, całkowicie odrębne, wzajemnie niezależne i głęboko różne, nastawione na, odpowiednio, postpublikacyjną i prepublikacyjną historię dzieła, łączy przynajmniej jeden rys charakterystyczny. Jak go najkrócej nazwać, określić? Może tak: fascynacja dynamiką tekstu, postrzeganego nie jako stabilny depozytariusz raz zadanego sensu, lecz jako (mniej lub bardziej intensywny) proces różnicującego powtórzenia. Właśnie ta zasadnicza, najogólniej ujęta konwergencja dwu badawczych optyk zachęca do pytania o możliwość uwspólniania terminologii, wymieniania doświadczeń. Propozycją odpowiedzi na takie pytanie jest niniejszy artykuł, a także, przywoływane już i omawiane, studium Veijo Pulkkinena.

Wydaje się jednak, że możliwa jest tu kooperacja bardziej zaawansowana, niepolegająca na pojęciowych zapożyczeniach czy adaptacjach, lecz na - połączeniu sił. Wyobrażam sobie jedną analityczno-interpretacyjną narrację, będącą , ,do połowy” krytyką genetyczną, „od połowy” zaś opisem publikacyjnych przygód tekstu. Warunkiem sine qua non takiej koalicji byłoby znalezienie specyficznego przedmiotu badań, charakteryzującego się podwójną atrakcyjnością: dla ciritique génétique i dla the politics of the page. Innymi słowy, musiałby to być tekst z jednej strony posiadający burzliwą przeszłość brulionową (liczne i radykalne przekształcenia sensu czy konstrukcji), taki na przykład, jak wiersz Herberta Dwaj prorocy. Próba głosu ${ }^{33}$, z drugiej zaś - ciekawą i długą historię edytorską, taki na przykład, jak sonet Emmy Lazarus pt. The New Colossus. Możliwa byłaby wówczas do przeprowadzenia narracja kompleksowa, opowiadająca dzieje tekstu najpierw rodzącego się na kartkach brulionów, później zaś wędrującego przez kartki kolejnych wydań i antologijnych przedruków, a nawet pamiątkowych tablic; najpierw obmyślanego przez autora, potem zaś od autora już oddzielonego, zmieniającego

${ }^{33} \mathrm{Na}$ temat historii powstawania tego wiersza (i zasadniczych przekształceń semantycznych, jakim w toku brulionowej pracy ulegał jego tekst) zob. Pracownia Herberta. Studia nad procesem tekstotwórczym, red. M. Antoniuk, Kraków 2017. 
swe bibliologiczne kody pod wpływem inwencji kolejnych pokoleń edytorów. A więc wciąż, nawet wiele lat czy dziesięcioleci po śmierci pisarza, niezastygłego w definitywnym kształcie.

Być może taką opowieść (takie opowieści) uda się zbudować polskim krytykom genetycznym, badaczom polskiego modernizmu materialnego?

\section{Bibliografia}

Arnheim R., Auden W.H., Shapiro K., Stauffer D., Poets at Work: Essays based on the modern poetry collection at the Lockwood Memorial Library, introduction by Ch. Abbot, New York 1948.

Benjamin W., Dzieło sztuki $w$ dobie reprodukcji technicznej, przeł. J. Sikorski [w:] idem, Anioł historii. Eseje, szkice, fragmenty, wybór i oprac. H. Orłowski, Poznań 1996, s. 201-239.

Biasi P.-M. de, Genetyka tekstów, przeł. F. Kwiatek, M. Prussak, Warszawa 2015.

Bornstein G., Material Modernism: The Politics of the Page, New York 2001.

Bradford C., Yeats at Work, Carbondale-Edwardsville 1965.

Dziadek A., Projekt krytyki somatycznej, Warszawa 2014.

Głowiński M., Poetyka Tuwima a polska tradycja literacka, Warszawa 1962.

Groden M., ,, Ulysses” in Progress, Princeton 1977.

Litz A.W., The Art of James Joyce: Method and Design in ,Ulysses” and ,Finnegans Wake", London 1961.

Ligęza W., „Homo patiens” Aleksandra Wata, „Znak” 1991, nr 2. Tekst włączony (w zmienionej wersji) do książki: W. Ligęza, Jaśniejsze strony katastrofy, Kraków 2001, s. 78-91.

Pietrych K., Co poezji po bólu? Empatyczne przestrzenie lektury, Łódź 2009.

Pulkkinen V., A Genetic and Semiotic Approach to the Bibliographical Code Exemplified by the Typography of Aaro Hellaakoski’' „Dolce far Niente”, „Variants” 2013, nr 10, s. 163-186.

Stala M., Buchalteria (Aleksander Wat) [w:] idem, Blisko wiersza: 30 interpretacji, Kraków 2013, s. 73-80.

Stala M., W stronę Lemanu [w:] idem, Chwile pewności: 20 szkiców o poezji i krytyce, Kraków 1991.

Wat A., Wybór wierszy, oprac. A. Dziadek, Wrocław 2008.

Zieliński J., Dwudziestowieczny Marsjasz, posłowie do: A. Wat, Poezje, Warszawa 1997.

Zieliński J., Kłacza - (kłonice) - synapsy (Posłowie) [w:] A. Wat, Notatniki, transkrypcja i oprac. A. Dziadek, J. Zieliński, Warszawa 2015. 